\title{
Studies on Myoinositol
}

\section{Removal of Deposited Fats from Dietary Fatty Liver}

\author{
IkUo Nishigaki, Syed H. Hasan, Akira Kotaki, \\ Kunio Yagi, Sumihiko OKuYama,* Shozo Ito,* \\ Kozo Yamada* AND Kazuo Yamashita ${ }^{* * 1}$
}

\author{
Institute of Biochemistry, *Department of Internal \\ Medicine, **Department of Anatomy, Faculty of \\ Medicine, University of Nagoya, Nagoya
}

(Post No. 466)

(Received April 21, 1971)

1. Electron microscopic observations have shown that when dietary fatty liver is induced in rats, the intracellular structure of the liver parenchymal cells is considerably deformed due to depositions of fat droplets in the cytoplasm. Such changes are considerably recovered by treating rats for a week with myoinositol; the reduction of the size and the number of fat droplets is evident and the lamellar structure of the rough-surfaced endoplasmic reticulum becomes distinct.

2. Histological comparison of the liver sections before and after the perfusion of the isolated dietary fatty liver indicated that myoinositol, when added to the perfusate, accelerates the movement of fats from the liver to the artificial blood stream. This was confirmed by chemical analysis of the blood before and after the perfusion.

3. Similar acceleration of the removal of fats by this cyclitol was observed in the hepatic cellular level regardless of the presence of infiltrated fats in the cytoplasm.

It has been well-established that when rats are stunted on high carbohydrate, low protein diet without $\mathrm{B}$ vitamin complex for three weeks and then treated for a week with subcutaneous injection of the $\mathrm{B}$ vitamin complex with no choline and myoinositol, a massive amount of fats and cholesterol is accumulated in their livers (1). On the development of this type of "dietary fatty liver", it has been reported $(2,3)$ that myoinositol, when it is administered with B vitamins, shows a definite preventive effect. It has also been proved that the typically developed fatty liver condition can be repaired to a great extent by injecting myo- inositol (4). As to the mechanism of the action of the cyclitol, it was found that the myoinositol administered enlarges the myoinositol pool to accelerate the synthesis of transferable phosphatidylinositol, which could then be utilized for the production of $\beta$-lipoprotein in the endoplasmic reticulum or for its transport from the liver to the blood stream (5). It was also found by in vivo experiments of fatty liver that the incorporation of ${ }^{14} \mathrm{C}$-leucine into plasma $\beta$-lipoprotein as well as into microsomal protein was elevated by administering myoinositol as compared with fatty liver control (6). It is therefore important to test whether

1 西垣郁雄, S. H. Hasan, 小滝 祥, 八木国夫, 奥山澄彦, 伊藤庄三, 山田弘三, 山下和雄. 
such acceleration mechanism occurs undoubtedly in the liver, by using an isolated system. Reported herein is the effect of myoinositol on the removal of fats from perfused fatty liver and from fatty liver slices. In the present paper, electron microscopic observations on the curative effect of this cyclitol are described, in relation to the data obtained by chemical analysis.

\section{Materials ANd Methods}

\section{Animals}

Male albino rats of Wistar strain, weighing about $100 \mathrm{~g}$, were used. For the induction of fatty liver, rats were placed on Handler's low protein, high carbohydrate diet (3) (free from $B$ vitamins, fats and cholesterol) for the total period of four weeks. In the fourth week they were given $\mathrm{B}$ vitamins (thiamine hydrochloride $25 \mu \mathrm{g}$, riboflavin $30 \mu \mathrm{g}$, calcium pantothenate $100 \mu \mathrm{g}$, pyridoxine hydrochloride $20 \mu \mathrm{g}$, nicotinamide $50 \mu \mathrm{g}$ and $p$-aminobenzoic acid $100 \mu \mathrm{g}$ per rat per day) subcutaneously.

2. Administration of Myoinositol in in vivo Experiments

Administration of myoinositol was made according to the method described in a previous paper (4).

\section{Light Microscopy}

To detect lipids in the liver tissue, small fragments of liver were fixed in $10 \%$ aqueous formaldehyde solution, frozen in dry ice, and the frozen tissues were cut into 10 micron sections. After staining with Sudan III, the sections were examined under the microscope.

\section{Electron Microscopy}

Small fragments of the liver were excised out from various portions of the organ and cut into small pieces in a cold fixative consisting of $1 \% \mathrm{OsO}_{4}$ bufferized to $\mathrm{pH} 7.4$ with $\mathrm{m} / 15$ phosphate buffer, containing $40 \mathrm{mg} / \mathrm{ml}$ sucrose and fixed for 2 hours at $0^{\circ}$. Then they were dehydrated in ascending concentrations of ethanol and embedded in Epon (7). Ultrathin sections were prepared by a Porter-Blum MT-1 type ultramicrotome and stained doubly with uranyl acetate (8) and lead citrate (9). The stained sections were examined with a Hitachi 11-A type electron microscope.

\section{Liver Perfusion}

Perfusion apparatus used is a device of Miller et al. (10). Rat blood, diluted with a half volume of Ringer solution, was used as perfusate. Blood was collected from abdominal aorta of albino rats (weighing about $250 \mathrm{~g}$ ), anesthetized with ether, by means of a syringe rinsed with heparin. For each run of perfusion, $150 \mathrm{ml}(65 \mathrm{ml}$ in the cases of chemical analysis) of perfusate was used. To examine the effect of myoinositol, it was added to the perfusate to a final concentration of $2 \mathrm{mg}$ per $\mathrm{ml}$. Before sectioning the fatty liver from the animal, bile duct was catheterized, a cannula connected to the portal vein, and the hepatic vein severed below the diaphragm. The liver thus removed was connected immediately with the apparatus by means of the portal vein cannula and the circulation restored by pumping the perfusate using a Sigma-motor. The perfusate was oxygenated continuously in the artificial lung, with a mixture of $95 \% \mathrm{O}_{2}$ and $5 \% \mathrm{CO}_{2}$. Perfusion was made at the pressure of $8-10 \mathrm{~cm} \mathrm{H}_{2} \mathrm{O}$, at the rate of $5-8 \mathrm{ml} / \mathrm{min}$, and at $40-42^{\circ}$. Aliquots $(10 \mathrm{ml})$ of the perfusate were collected before and after perfusion. Total lipids in the perfusate were extracted according to Folch and Lees (11) and measured gravimetrically. Separation of $\beta$-lipoprotein was carried out by a slightly modified method (6) of Burstein and Samaille (12) and the cholesterol content in it was measured according to Zlatkis et al. (13). The bile flow was used as a check for the life of the organ during the perfusion. Liver sections for microscopic observation were prepared before and after the perfusion.

\section{Experiments with Liver Slices}

The liver slices were prepared using an ordinary slicer. The slices (about $12 \mathrm{mg}$ as protein) were pre-incubated in a vessel containing $20 \mathrm{ml}$ of Krebs-Ringer bicarbonate buffer, $\mathrm{pH} 7.4$, for $45 \mathrm{~min}$ at $37^{\circ}$. The slices were then placed in $10 \mathrm{ml}$ of the fresh buffer, and incubated at $37^{\circ}$ for 2 hours under the gas phase composed of $95 \% \mathrm{O}_{2}$ and $5 \% \mathrm{CO}_{2} . \beta$. Lipoprotein released in the media was precipitated as described in the previous report (6) 
and the protein content in the precipitate was estimated according to Lowry et al. (14).

\section{RESUlTS}

1. Histological Observations on the Effect of Myoinositol on Fatty Liver

Photograph 1 shows the electron micrographs of normal liver, fatty liver treated and not treated with myoinositol, which are equally magnified. In fatty liver (Photograph 1 middle), most of the cytoplasm of parenchymal cell is displaced by many fat droplets and the fewer cell organelles are seen to be in a disorderly manner, and the lamellar structure of the roughsurfaced endoplasmic reticulum is deformed.

However, as shown in Photograph 1 bottom, considerable reduction of the size and number of fat droplets is seen when rats suffering from fatty liver were treated with myoinositol. The deranged cell organelles are considerably repaired and the lamellar structure of the rough-surfaced endoplasmic reticulum has become distinct. These results are in accord with the previous observations (6) that the hepatic protein synthesis, which is inhibited when rats are suffering from fatty liver, is increased by curing the fatty liver with myoinositol.

\section{Liver Perfusion}

Photograph 2 shows micrographs of Sudan III stained sections of isolated fatty liver before and after the 4 hours' perfusion with the perfusate containing myoinositol $(2 \mathrm{mg} / \mathrm{ml})$. The removal of deposited fats is evident, which is hardly observed in the control run where myoinositol is not added to the perfusate. Since indication of this cyclitol's effect on the removal of fats from : the isolated liver was difficult in so far as it is monitored by the measurement of changes in the lipid content of a large volume of rat blood in perfusate, perfusions for the chemical analysis were carried out with as small volume of perfusate $(65 \mathrm{ml})$ as possible. The effect of myoinositol on the release of fats from fatty liver into the blood perfused for 3 hours was tested. The results are shown in Table 1. It is evident from these histological
TABLE 1

The effect of myoinositol on the total lipids and $\beta$-lipoprotein cholesterol content released from fatty liver into the blood perfused $a$

\begin{tabular}{|c|c|c|c|}
\hline \multirow[b]{2}{*}{$\begin{array}{l}\text { Addition of myoinositol } \\
(2 \mathrm{mg} / \mathrm{ml} \text { perfusate })\end{array}$} & \multicolumn{2}{|c|}{ Total lipids } & \multirow{2}{*}{$\begin{array}{c}\begin{array}{c}\beta \text {-Lipoprotein } \\
\text { cholesterol }\end{array} \\
+ \\
+\end{array}$} \\
\hline & - & + & \\
\hline & \multicolumn{2}{|c|}{$\underset{\text { perfusate }}{m g / m l}$} & $\underset{\text { perfusate }}{\mu g / m l}$ \\
\hline Before perfusion & 6.2 & 5.9 & 92.5 \\
\hline \multirow[t]{2}{*}{ After perfusion } & 6.7 & 8.1 & 99.6 \\
\hline & \multicolumn{2}{|c|}{$m g$} & $\mu g$ \\
\hline Total amount released & 33 & 143 & 426 \\
\hline
\end{tabular}

$a$ Values are the average of 5 experiments.

TABLE 2

The effect of myoinositol on the content of B-lipoprotein released from liver slices into me. dium incubated ${ }^{a}$

\begin{tabular}{cccccc}
\hline \hline & Normal liver & Fatty liver \\
\hline $\begin{array}{c}\text { Addition of myoinositol } \\
(10 \mathrm{mg} / \mathrm{ml})\end{array}$ & - & + & - & + \\
\hline & $\mu g$ & protein/mg & tissue protein \\
& 6.6 & 7.5 & 6.3 & 9.1 \\
\hline
\end{tabular}

$a$ Values are average of 5 experiments.

and analytical results that this cyclitol accelerates the movement of fats, possibly in the form of $\beta$-lipoprotein, from fatty liver into the perfusate.

\section{Experiments with Liver Slices}

The effect of myoinositol on the secretion of $\beta$-lipoprotein from the liver was further tested by incubating the liver slices in the media with and without myoinositol $(10 \mathrm{mg} / \mathrm{ml})$. The results are shown in Table 2. It is obvious from these data that this cyclitol stimulates the extrusion of $\beta$-lipoprotein from the cell to the media. This effect is observable in the experiments on both the normal and fatty liver and it is more noticeable in the latter case.

\section{Discussion}

As mentioned in the introductory part of this paper, the lipotropic action of myoinositol could be attributed so far to a) the rapid increase of phosphatidyl-inositol, which can contribute to the formation of $\beta$-lipoprotein or 

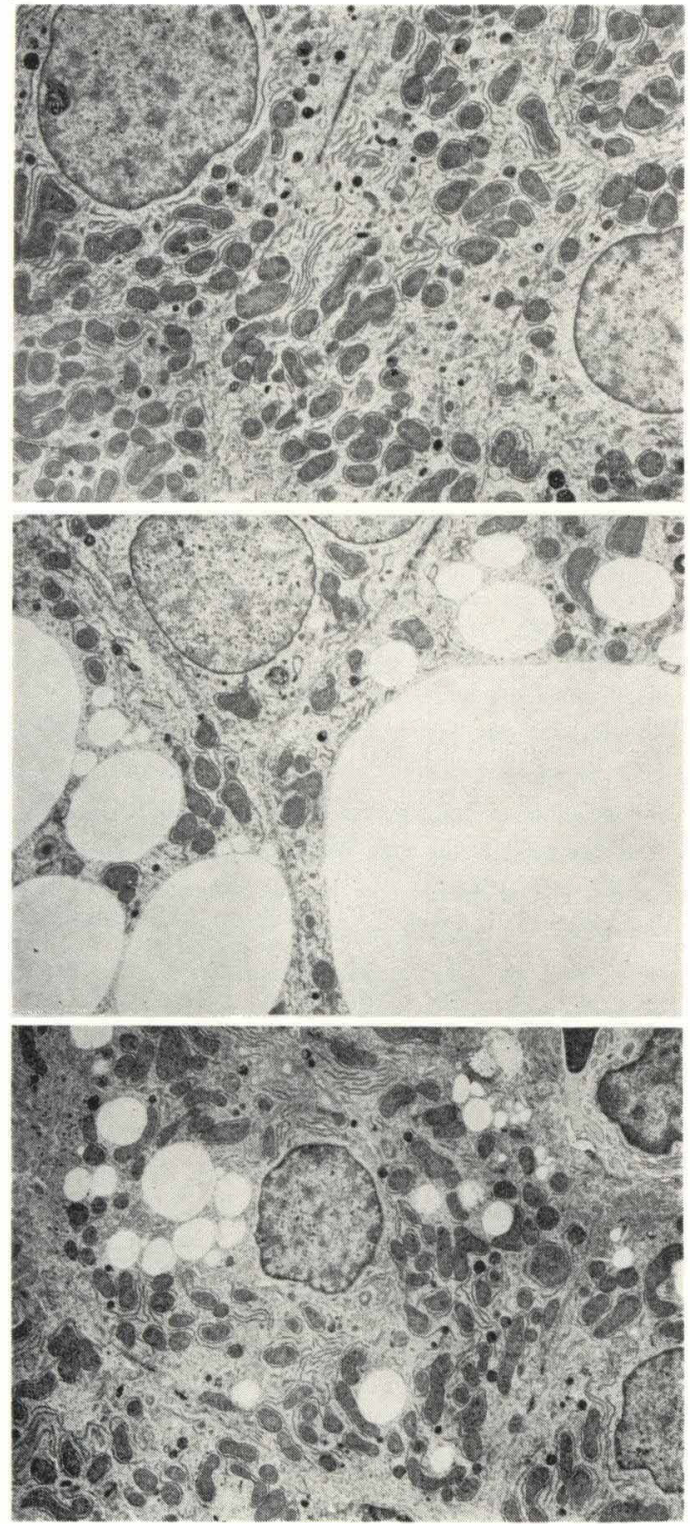
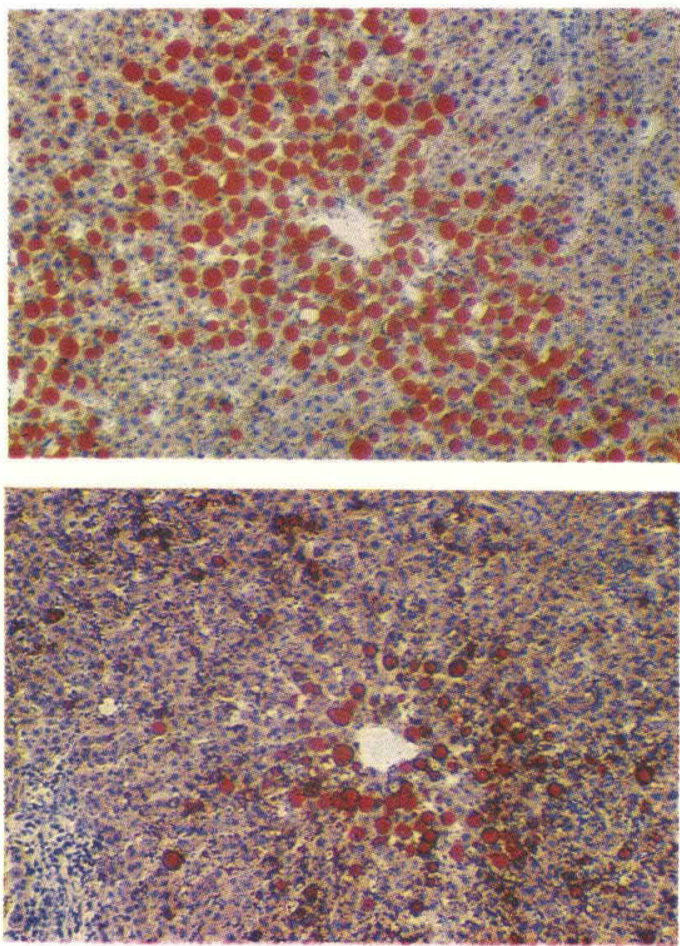

Photograph 2. Micrographs of Sudan III stained sections of isolated fatty liver before and after the 4 hours perfusion with diluted rat blood containing myoinositol $(2 \mathrm{mg} / \mathrm{ml})$

Top: before perfusion; bottom : after perfusion

PHOTOGRAPH 1. Electron micrographs of livers

Top: normal liver; middle: fatty liver; bottom : fatty liver after treatment with myoinositol. 
to its transport from the liver, and b) recovery or promotion of microsomal protein synthesis. The present study using perfusion experiment revealed the removal of deposited fats from the perfused fatty liver to the artificial blood stream. This was confirmed by both histological observation and chemical analysis. It clearly indicates that the effect of myoinositol on the removal of deposited fats from the liver to the other tissues such as adipose tissue can be principally attributed to the liver. This effect was further demonstrated using liver slices, indicating that the mechanism is involved in cell functions. In considering the overall mechanism of the transportation of fats from the liver, the disposition of the other tissues which accept the transported fats should also be considered.

The electron microscopic observation made in the present study has shown that morphological change in arrangement of the roughsurfaced endoplasmic reticulum, which is thought to be the site for protein synthesis, of the liver parenchymal cells is obvious and its quantity decreases considerably, when the liver accumulates fats as a result of nutritional imbalance. However, such a fatty liver condition is markedly recovered when rats suffering from fatty liver are treated with myoinositol. This result is compatible with the previous result (6) that the disturbed protein synthesis in the fatty liver is recovered considerably upon administration of myoinositol for a week.
These results indicate that for protein synthesis the structural integrity in rough-surfaced endoplasmic reticulum is important, to which phosphatidyl-inositol formed from added myoinositol could contribute.

\section{REFERENCES}

1. Gavin, G., and McHenry, E. W., J. Biol. Chem., 139, 485 (1941).

2. MacFarland, M. L., and McHenry, E.W., J. Biol. Chem., 176, 492 (1948).

3. Handler, P., J. Biol. Chem., 162, 77 (1946).

4. Kotaki, A., Sakurai, T., Kobayashi, M., and Yagi, K., J. Vitaminol., 14, 87 (1968).

5. Yagi, K., and Kotaki, A., Ann. N. Y. Acad. Sci., 165, 710 (1969).

6. Hasan, S. H., Kotaki, A., and Yagi, K., J. Vitaminol., 16, 144 (1970).

7. Coulter, H. D., J. Ultrastruct. Res., 20, 346 (1967).

8. Reynolds, E. S., J. Cell Biol., 17, 208 (1963).

9. Stempak, J. C., and Ward, R. T., J. Cell Biol., 22, 697 (1964).

10. Miller, L.L., Bly, C.G., Watson, M.L., and Bale, W.F., J. Exp. Med., 94, 431 (1951).

11. Folch, J., and Lees, M., J. Biol. Chem., 226, 497 (1957).

12. Burstein, M., and Samaille, J., J. Physiol., 49, 83 (1957).

13. Zlatkis, A., Zak, B., and Boyle, A. J., J. Lab. Clin. Med., 41, 486 (1953).

14. Lowry, O. H., Rosenbrough, N. J., Farr, A. L., and Randall, R. T., J. Biol. Chem., 193, 265 (1951). 